\title{
Tindak Tutur Direktif Guru dalam Pembelajaran Bahasa Indonesia di SMA Negeri 2 Gunung Talang
}

\author{
Teacher Directive Speaking Action In Indonesian Learning \\ at SMA Negeri 2 Gunung Talang
}

\author{
Yulia Marizal ${ }^{1, *}$, Sayhrul R. ${ }^{2}$, dan Tressyalina ${ }^{3}$ \\ ${ }^{1}$ Magister Pendidikan Bahasa dan Sastra Indonesia, \\ FBS, Universitas Negeri Padang \\ ${ }^{2,3}$ Fakultas Bahasa dan Seni, Univeristas Negeri Padang \\ ${ }^{1}$ Corresponding email: marizalyulia14@gmail.com \\ ${ }^{2}$ Email: syahrul r@fbs.unp.ac.id \\ ${ }^{3}$ Email: tressyalina@fbs.unp.ac.id
}

Received: 30 June 2021 Accepted: 21 September 2021 Published: 5 November 2021

\begin{abstract}
This study aimed to describe the form of teacher directive speech acts in learning Indonesian at SMA Negeri 2 Gunung Talang. This type of research is qualitative research with a descriptive method. The research data used is the teacher's speech in learning Indonesian at SMA Negeri 2 Gunung Talang. The data source is Mrs. Indra Dewi as an Indonesian teacher at SMA Negeri 2 Gunung Talang. The data collection technique used the free-of-conversation listening technique. Data analysis techniques are listening, understanding, organizing, categorizing, connecting between categories, and interpreting data based on the context. The results of this study contained five forms of directive speech acts, namely requesting speech, wishing speech, commanding speech, welcome speech, and asking speech. The utterance asks to be reviewed from the words "please" and "come on. "Speeches of hope are viewed from the word "hope" or "hope. "Speech orders are reviewed from the words "try" and "quick." Speech please viewed from the word "please." Asking utterances are viewed from the words "what," "who, " and "how."

Keywords: speech act, directive, teacher
\end{abstract}

\begin{abstract}
Abstrak: Tujuan penelitian ini adalah untuk mendeskripsikan bentuk tindak tutur direktif guru dalam pembelajaran Bahasa Indonesia di SMA Negeri 2 Gunung Talang. Jenis penelitian ini adalah penelitian kualitatif dengan metode deskriptif. Data penelitian yang digunakan yaitu tuturan guru dalam pembelajaran Bahasa Indonesia di SMA Negeri 2 Gunung Talang. Sumber data yaitu Ibu Indra Dewi selaku guru Bahasa Indonesia di SMA Negeri 2 Gunung Talang. Teknik pengumpulan data menggunakan teknik simak bebas libat cakap. Teknik analisis data dengan menyimak, memahami, menata, mengkategorikan, menghubungkan antar kategori, dan menginterpretasi data berdasarkan konteksnya. Hasil penelitian ini terdapat lima bentuk tindak tutur direktif, yaitu tuturan meminta, tuturan harapan, tuturan perintah, tuturan persilakan, dan tuturan bertanya. Tuturan meminta ditinjau dari kata tolong dan ayo. Tuturan harapan ditinjau dari kata harap atau harapan. Tuturan perintah ditinjau dari kata coba dan cepat. Tuturan persilakan ditinjau dari kata silakan. Tuturan bertanya ditinjau dari kata apa, siapa, dan bagaimana.
\end{abstract}

Kata kunci: tindak tutur, direktif, guru

To cite this article:

Marizal, Y., Sayhrul R., \& Tressyalina. (2021). Tindak Tutur Direktif Guru dalam Pembelajaran Bahasa Indonesia di SMA Negeri 2 Gunung Talang. Diglosia: Jurnal Kajian Bahasa, Sastra, dan Pengajarannya, 4(4), 441452. https://doi.org/10.30872/diglosia.v4i4.264 


\section{A. PENDAHULUAN}

Fungsi bahasa dalam kehidupan dijadikan sebagai alat berkomunikasi yang dipergunakan manusia dalam berinteraksi dengan manusia lainnya. Gawen menyatakan bahwa bahasa merupakan suatu rekayas teknologi yang dikemas untuk pengetahuan (mind) yang menghimpun, memperoleh, memproses, menyebarkan, serta mewariskan pengetahuan yang diterima atau yang diberikan (Nurhamida \& Tressyalina, 2019, p. 21). Dari bahasa tersebut terdapat proses komunikasi yang terjadi melalui komunikasi yang bersifat verbal dan komunikasi yang berisfat nonverbal. Komunikasi yang bersifat verbal berarti cara berkomunikasi yang berkaitan dengan bahasa lisan seperti menyuruh, memohon, dan menyarankan. Sementara itu, komunikasi nonverbal berarti komunikasi yang tidak mengeluarkan kata-kata dari pancaindera, melainkan gerakan isyarat berupa gesture tubuh (Maryunis et al., 2012, p. 73).

Bahasa juga dipakai dalam pragmatik. Pragmatik disebut juga sebagai ilmu bahasa yang mempelajari tuturan sebagai cara berkomunikasi dengan menggunakan bahasa yang benar dalam pengucapan sehingga apa yang disampaikan dapat dipahami oleh pendengar. Untuk itu, diperlukan pemahaman yang kompeherensif dalam pendekatan pragmatik, sehingga menciptakan tuturan, implikatur, konteks, dan praanggapan. Bahasa dan komunikasi tidak dapat dipisahkan. Dalam berkomunikasi terdapat bahasa primer, hal ini akan terbentuknya sebuah komunikasi. Oleh karena itu, manusia sebagai makhluk sosial, dapat berkomunikasi sesuai yang dibutuhkan untuk melanjutkan kehidupannya sebagai makhluk sosial. maka, diperlukan komunikasi dengan bahasa yang baik dan benar (Falia et al., 2018, p. 114).

Levinson mengatakan bahwa pragmatik adalah sebuah ilmu bahasa yang membahas hubungan bahasa dengan konteks berdasarkan penjelasan dari bahasa tersebut. Maksudnya, dapat dimengerti sesuatu ucapan bahasa yang diolah melalui pengetahuan dari luar, seperti makna kata atau kalimat, serta hubungannya dengan konteks pemakainya (Hermita et al., 2014, p. 63) . Sejalan dengan itu, Verhaar juga berpendapat bahwa pragmatik sebagai cabang dari ilmu linguistik yang mengkaji terkait struktur dalam bahasa yang dijadikan sebagai alat komunikasi diantara penutur dengan mitra tutur, serta menjadi acuan dari tanda-tanda bahasa ekstralingual yang dibahasnya (Putra, 2020, p. 31).

Dalam tindak tutur juga ada beberapa unsur yang terdapat didalamnya, yaitu siapa yang berbicara, dengan siapa dia berbicara, mengenai siapa dan apan, serta jalur apa (Tressyalina \& Anisa, 2020, p. 254). Dalam proses berkomunikasi yang efektif dan interaktif, pada dasarnya ada dua orang yang terlibat dalam situasi tersebut, yaitu penutur dan mitra tutur. Seorang penutur dapat dikatakan sebagai orang yang memberikan informasi, sedangkan mitra tutur dikatakan sebagai orang yang menerima informasi dari penutur. Jadi, jika informasi yang disampaikan oleh penutur tercapai dengan baik dan diterima lawan tutur, maka bisa dikatakan bahwa komunikasi atau interaksi tersebut berjalan dengan lancar. Terkadang yang sering terjadi di masyarakat atau lingkungan sosial kita, dalam penggunaan bahasa menggunakan tuturan yang mungkin saja sulit untuk dipahami oleh mitra tutur. Oleh sebab itu, kita sebagai lawan tutur harus mengerti arti dari tuturan dan makna yang disampaikan oleh si pembicara. Tidak hanya itu, kita juga harus mengerti akan konteks yang dipakai dalam ujaran tersebut. Tuturan bermanfaat untuk memberikan informasi mengenai sesuatu, kemudian juga untuk memberikan ekspresi terkait apa 
dan bagaimana yang dirasakan oleh penutur. Kegiatan ini berkaitan dengan tindak tutur. Syukur et al. (2020, p. 447) juga menyampaikan bahwa tindak tutur disebut juga sebagai gejala individual dan keberlangsungan komunikasi yang ditentukan dengan menilai kemampuan dari penutur dalam berbahasa, sedangkan peristiwa tutur merupakan sebuah gejala bermasyarakat.

Leech mengatakan bahwa tindak tutur disebut sebagai tindakan dalam mengungkapkan bahasa yang diselingi dengan sikap dan gerak tubuh yang mendukung maksud dari tuturan yang akan disampaikan (Imaniar, 2013, p. 20). Kemudian, Atmazaki mengemukakan tindak tutur berdasarkan situasi ujar, seperti (a) penutur, (b) konteks, (c) tujuan, (d) tindakan, (e) produk tindak verbal. Tindak tutur merupakan seluk beluk dari sesuatu yang dikatakan dan dilakukan sesuai dengan konteks dan reaksi yang diharapkan (Tressyalina \& Anisa, 2020, p. 22). Selain itu, Sunarwan et al. (2014, p. 29) juga menjelaskan bahwa terdapat suatu gejala individual psikologis dan keberlangsungan komunikasi terkait kemampuan penutur dalam menghadapi situasi. Makanya, tuturan dapat ditinjau dari makna tindakan tersebut.

Di dalam pragmatik, terdapat tiga pembagian dalam tindak tutur, yaitu tuturan lokusi, tuturan ilokusi, dan tuturan perlokusi. Lokusi berarti tuturan yang maknanya disesuaikan dengan tuturan penutur. Kemudian, ilokusi berarti tuturan yang akan melakukan sesuatu berkaitan dengan peran dan tujuan dari tuturan. Terakhir, perlokusi berarti tuturan yang memiliki efek bagi lawan tuturnya. Searle mengemukakan lima kriteria tuturan ilokusi, yaitu representatif, direktif, ekspresif, komisif, dan deklarasi. (a) representatif yakni sebuah tuturan yang terkait pada sesuatu hal yang benar atas apa yang dikatakan, seperti pernyataan, laporan, tunjukkan dan sebutkan. (b) direktif yakni sebuah tuturan yang memiliki tujuan supaya mitra tutur dapat melaksanakan tindakan/perintah yang dimaksud dalam ujaran penutur, seperti suruhan, permohonan, tuntutan, saran dan tantangan. (c) ekspresif yakni tuturan yang dapat dihasilkan dengan tujuan supaya ujaran yang dimaksudkan dapat dievaluasi mengenai hal yang diucapkan dalam ujaran penutur, seperti pujian, ucapan terima kasih, kritikan dan keluhan. (d) komisif yakni tuturan yang terikat pada lawan tutur untuk melaksanakan yang dimaksudkan dalam ujaran pembicara, seperti janji, sumpah dan ancaman. (e) deklarasi yakni tuturan yang diucapkan penutur dengan tujuan supaya dapat menciptakan hal yang baru seperti status dan keadaan, seperti keputusa, larangan, izin, dan memberi maaf (Elmita et al., 2013, p.139).

Tuturan direktif merupakan tuturan yang berupaya agar lawan tutur dapat melaksanakan suatu yang disampaikan oleh pembicara, seperti suruhan, permohonan, dan menantang (Elmita et al., 2013, p. 140). Sejalan dengan itu, Yule juga mengatakan bahwa direktif dipakai untuk menyuruh mitra tutur yang dilakukan penutur untuk melakukan sesuatu. Selain itu, agar mitra tutur mengerti dan dapat melakukan ucapan yang diujarkan penutur (Vilayati et al., 2012:546). Kemudian, Rahardi juga menyampaikan bahwa tuturan direktif ini juga merupakan ujaran yang bertujuan agar penutur dapat memberikan pengaruh kepada lawan tutur supaya melakukan tindakan, seperti memesan, perintah, permohonan dan nasihat (Elmita et al., 2013, p. 140).

Searle mengungkapkan ada beberapa tindak tutur direktif yaitu (a) tindak tutur menyuruh bertujuan memperintah lawan tutur agar dapat melaksanakan apa yang pembicara sampaikan, (b) tindak tutur memohon yang bertujuan untuk meminta 
kepada lawan tutur untuk melaksanakan sesuatu yang diharapkan pembicara, (c) tindak tutur direktif berupa menyarankan bertujuan agar dapat menyarankan mitra tutur supaya dapat melaksanakan sesuatu berupa pendapat yang menurut pembicara baik bagi lawan tutur dan pembicara tersebut, (d) tindak tutur direktif berupa menasihati yang bertujuan untuk memberikan nasihat kepada lawan tutur mengenai apa yang dikerjakan dan (e) tindak tutur direktif berupa menantang bertujuan agar dapat memotivasi mitra tutur supaya dapat melaksanakan sesuatu yang dikatakan. Melalui tindak tutur direktif, pembicara berusaha supaya lawan tutur tertantang untuk mengerjakan apa yang dibicarakannya (Elmita et al., 2013, p. 140).

Temuan lainnya yang melakukan penelitian mengenai tindak tutur direktif ini ada peneliti Kaka (2017) yang berjudul Analisis terhadap Kesantunan Tindak Tutur Direktif Guru dalam Pembelajaran di SD Inpres Bajawa VI Kecamatan Bajawa Kabupaten Ngada, yang mengungkapkan bahwa dapat menghindari ancaman dari tindakan direktif dan tindakan ekspresif, maka guru harus memakai startegi yang santun dalam proses pembelajaran di kelas. Selanjutnya, penelitian yang dilakukan oleh Wati et al. (2017) yang berjudul Tindak Tutur Direktif Guru Perempuan dalam Pembelajaran Bahasa Indonesia Kelas XI SMA yang mengungkapkan bahwa pada dasarkan guru perempuan sering merealisasikan tuturannya pada tindak tutur langsung dnegan fungsi memerintah. Kemudian, penelitian yang dilakukan oleh Darwis \& Ketut (2018) yang berjudul Tindak Tutur Direktif Guru di Lingkungan SMP Negeri 19 Palu: Kajian Pragmatik juga menyarankan bahwa fungsi dari tuturan langsung atau tuturan tidak langsung perlu untuk dipertimbangkan keberadaan dari partisipan yang akan dihadapi, karena pertimbangan ini yang akan menentukan pilihan dalam melakukan tuturan. Tuturan langsung terdiri atas tuturan perintah dan bertanya, dan sebaliknya tuturan tidak langsung terdiri atas tuturan meminta, memerintah, dan melarang.

Salah satu tempat yang menghasilkan interaksi sosial yang banyak adalah sekolah. Sekolah melibatkan tindak tutur sebagai proses interaksi, khuusnya dalam pembelajaran antara guru dan siswa ataupun masyarakat yang terlibat (Larassaty et al., 2016, pp. 431-437). Kemampuan komunikasi menjadi faktor pemicu yang dibutuhkan guru dalam menyampaikan petunjuk dan pesan atau arahan dalam pembelajaran kepada siswa. Dengan memberikan petunjuk, maka pengelolaan interkasi pembelajaran akan berjalan dengan efektif (Prasetyo, 2018, p. 3).

Ketika berada di kelas, guru memiliki kekuasaan untuk mengontrol kelas, termasuk siswa. Guru sebagai orang yang menyampaikan informasi dan siswa sebagai orang yang menerima informasi sehingga statusnya lebih rendah di kelas, agar dapat diatur dalam batasan tertentu. Pemilik dari kekuasaan dalam mengontrol siswa adalah peran khusus dari guru di kelas. Berdasarkan peranan yang dimiliki oleh guru tersebut, guru juga memiliki hak dalam pengelolaan kelas, mengatur siapa, berapa, dan kapan siswa mengemukakan pendapat, mengatur pertanyaan, evaluasi jawaban, dan mengemukakan umpan balik. Konteks ini bermaksud bahwa tindak tutur direktif untuk menyampaikan fungsi komunikasi tertentu ketika berinteraksi pada proses pembelajaran di kelas yang dipakai oleh guru (Ardianto, 2013, p. 4). Hal ini sejalan dengan, Sanjaya juga menyatakan bahwa peranan guru dalam pembelajaran itu sangat penting, seperti sebagai referensi belajar, fasilitator, demonstrator, pengelola, pembimbing, motivator, dan evaluator (Yuliana et al., 2013, p. 2). 
Menurut Sumarti (2015, p. 64), ada upaya yang mewujudkan pembelajaran agar mampu dikondisikan oleh peserta didik agar memiliki kompetensi yang optimal dan maksimal dengan melakukan strategi tindak tutur guru sebagai pemicu tumbuhnya aktualisasi pada peserta didik. Sejalan dengan itu, Sinclair dan Brazil mengatakan bahwa dalam penggunaan tindak tutur direktif guru, seharusnya efektif agar tujuan dalam interaksi pada pembelajaran di kelas tercapai dengan maksimal. Keefektifan guru di kelas sangat penting karena kelas merupakan tempat dimana siswa mengampu pendidik melalui pembelajaran dan mempraktikkan keterampilan untuk meningkatkan kemampuan komunikatif siswa tersebut (Ardianto, 2013, p. 3). Selain itu, Cook juga berpendapat bahwa makna pembelajaran melalui interaksi lisan guru dan siswa di kelas dipengaruhi oleh penggunaan bahasa guru itu sendiri. Bahasa yang digunakan oleh guru di kelas dapat mempengaruhi kesuksesan interaksi pembelajaran dalam mencapai tujuan pendidikan. Untuk menjaga hal tersebut, pembelajaran melalui interaksi lisan di kelas guru harus menggunakan bahasa yang berstrategis. Dengan itu, guru harus menyesuaikannya dengan konteks, topik, hubungan (sosial dan psikologis) yang akan menentukan tingkat keefektifan komunikasi guru dengan siswa selama kegiatan pembelajaran di kelas (Ardianto, 2013, p. 3).

Berdasarkan penjelasan di atas, maka tujuan dari penelitian ini adalah mendeskripsikan bentuk tindak tutur direktif guru pada pembelajaran Bahasa Indonesia di SMA Negeri 2 Gunung Talang.

\section{B. METODE}

Penelitian ini menggunakan pendekatan kualitatif dengan metode deskriptif. Penelitian kualitatif dilakukan untuk menemukan gambaran yang jelas, objektif, sistematis, dan teliti terkait fakta yang didapat dari tindak tutur direktif guru Bahasa Indonesia. Sebaliknya, metode deskriptif yang dilakukan oleh peneliti untuk memberikan gambaran mengenai suatu konsep yang berhubungan dengan subjek penelitian yaitu tindak tutur direktif guru.

Data penelitian yang digunakan berupa tuturan guru Bahasa Indonesia dalam pembelajaran berupa bentuk tuturan direktif di SMA Negeri 2 Gunung Talang. Sumber data penelitian yang digunakan diperoleh dari informan yaitu guru Bahasa Indoneisa di SMA Negeri 2 Gunung Talang yang bernama Ibu Indra Dewi pada saat pembelajaran berlangsung. Teknik pengumpulan data menggunakan teknik simak bebas libat cakap karena peneliti hanya menyimak percakapan penutur dan mitra tutur tanpa harus ikut berdialog secara langsung. Teknik analisis data dimulai dari menyimak, memahami, menata, mengkategorikan, menghubungkan antar kategori, dan menginterpretasi data berdasarkan konteksnya.

\section{PEMBAHASAN}

Penutur melakukan tindak tutur direktif supaya lawan tutur dapat melaksanakan tindakan yang disampaikan dalam ujaran penutur. Tuturan direktif ini berupa tuturan perintah, pemesanan, permohonan, memberi saran, dan ajakan (Rahmawati, 2020). Hal ini dapat ditinjau dalam tuturan guru kepada siswa. Dalam menganalisis peranan konteks pada penggunaan bahasa ditentukan oleh makna yang diucapkan oleh penutur kepada lawantutur. Maksudnya, makna yang disebut adalah konteks, yaitu berisi siapa penutur, kepada siapa penutur bertutur, apa yang menjadi topik dalam bertutur, dalam hal/rangka apa penutur bertutur, tujuannya apa dan 
dimana lokasi bertutur, serta bagaimana hubungan antara penutur dengan lawan tutur. Berdasarkan hasil observasi yang dilakukan terhadap guru bahasa Indonesia pada saat pembelajaran di SMA Negeri 2 Gunung Talang, terdapat beberapa bentuk tuturan direktif guru kepada siswa, seperti bentuk meminta, harapan, perintah, dipersilakan, dan bertanya. Hasil penelitian ini dideskripsikan berdasarkan pengklasifikasian temuan dari lapangan yaitu sebagai berikut.

\section{Bentuk Tuturan Meminta}

Tindak tutur direktif berupa tuturan meminta diartikan sebagai permintaan dari pembicara kepada lawan tutur untuk melaksanakan sesuatu. Artinya, pembicara dan mitra tutur akan melakukan sesuatu atas keinginan dan kemauan dari si penutur. Oleh sebab itu, tuturan meminta ini dituturkan dengan cara halus/lembut atau keras tergantung bentuk keinginan yang disampaikan oleh penutur. Sering kali ditemui bahwa tuturan meminta memiliki bentuk suruhan yang halus sehingga nada bicara penutur ketika berbicara lebih merendah. Tuturan meminta ini ditandai dengan kata "tolong" dan "ayo".

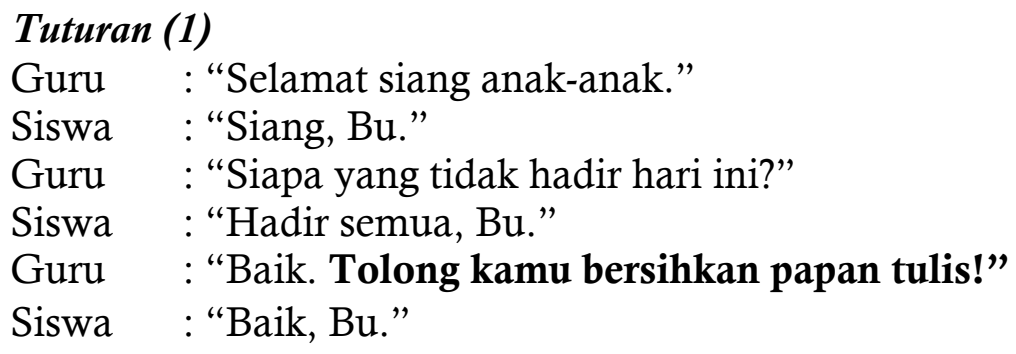

\section{Tuturan (2)}

Guru : "Selamat pagi anak-anak. Hari ini adalah hari pengambilan nilai baca puisi."

Siswa : "Iya, Bu."

Guru : "Ibu berharap semua Ananda mampu menunjukkan bakat Ananda."

Siswa : "Saya tidak bias baca puisi bu?"

Guru : "Tidak apa-apa, semua butuh proses. Ibu ingin Ananda semua melakukan yang terbaik menurut versi Ananda sekalian. Paham?"

Siswa : "Paham, Bu."

Guru : "Ayo cepat berbaris ke lapangan,pengambilan nilai baca puisi akan dimulai."

Siswa : "Baik, Bu."

Tuturan guru dari tuturan (1) dan (2) merupakan tuturan meminta dengan menggunakan penanda kata "tolong" dan "ayo" agar permintaan terkesan baik dan santun terhadap tuturan guru dan siswa. Konteks yang terjadi adalah guru sebagai orang yang menyampaikan informasi dan siswa sebagai orang yang menerima informasi. Topik tuturan (1), guru meminta siswa untuk membersihkan papan tulis karena guru akan menjelaskan materi pembelajaran dengan memanfaatkan papan tulis sebagai media pembelajaran. Konteks ini ditandai dengan kata "tolong" sebagai kata ungkapan dalam tindak tutur meminta sehingga menghasilkan tutur kata yang sopan ketika diucapkan secara langsung. Kemudian, topik tuturan (2) guru meminta 
siswa untuk segera berbaris di lapangan karena pengambilan nilai baca puisi akan dimulai. Dengan itu, guru meminta siswa dengan kata "ayo" yang dinilai sopan untuk dituturkan secara langsung.

\section{Bentuk Tuturan Harapan}

Tindak tutur direktif berupa tuturan harapan diartikan supaya siswa tidak merasa terbebani jika tidak mampu dalam mengemukakan pendapat yang diminta oleh guru. Misalnya, bentuk harapan dengan kata "harap" dapat ditinjau pada contoh berikut ini.

\section{Tuturan (3)}

Guru : "Apakah ada yang ingin ditanyakan mengenai materi pembelajaran kita hari ini?"

Siswa : "Tidak, Bu."

Guru : "Berarti semuanya sudah paham ya?"

Siswa : "Paham, Bu."

Guru : "Ibu harap Ananda semuanya memahami materi hari ini dan mengulang pembelajaran di rumah sehingga minggu depan kita bias kuis"

Siswa : "Baik, Bu."

\section{Tuturan (4)}

Guru : "Dalam pengambilan nilai baca puisi minggu lalu, hanya ada satu nama yang akan ikut lomba ke tingkat nasional."

Siswa : "Siapa bu?"

Guru : "Siswa ini memperoleh nilai 95 dengan intonasi yang jelas, pelafalan yang jelas, dan juga mengekspresikan diri dalam puisi tersebut."

Siswa : "Uzan, Bu."

Guru : "Fauzan Adriyansyah kamu memperoleh nilai terbaik."

Fauzan : "Terima kasih, Bu."

Guru : "Apa kamu bersedia mewakilkan nama sekolah ke tingkat nasional?"

Fauzan : "Bersedia, Bu."

Guru : "Harapan sekolah agar kamu bisa membawa nama baik sekolah pada lomba pembacaan puisi ke tingkat Provinsi"

Fauzan : "Iya, Bu."

Tuturan guru dari tuturan (3) dan (4) merupakan tuturan harapan dengan menggunakan penanda kata "harap-an" agar harapan atau permohonan dari tuturan guru terhadap siswa terkesan baik dan tersampaikan dengan lancar. Konteks yang terjadi adalah guru sebagai penutur dan siswa sebagai mita tutur. Topik tuturan (3) guru mengharapkan siswa dapat memahami materi yang disudah dijelaskan oleh guru dan dimengerti pada saat proses pembelajaran dengan ungkapan kata "harap" sehingga tuturan menjadi lebih sopan. Kemudian, topik tuturan (4) guru berharap kepada salah satu siswa di kelas untuk dapat meraih juara supaya membanggakan sekolah pada lomba pembacaan puisi tingkat Provinsi. Dalam hal ini, guru 
mengungkapkan rasa harapannya dengan mengatasnamakan sekolah kepada si siswa sebagai mitra tutur yang ditandai dengan kata "harapan".

\section{Bentuk Tuturan Perintah}

Tindak tutur direktif berupa tuturan perintah diartikan sebagai asumsi ketika penutur memerintahkan lawan tutur untuk melaksanakan suatu hal mengenai apa yang diinginkan oleh penutur, sehingga lawan tutur melakukannya sesuai yang diperintahkan oleh penutur. Tuturan menyuruh ini ditandai dengan penanda kesantunan "coba" dan kata "cepat" sebagai berikut.

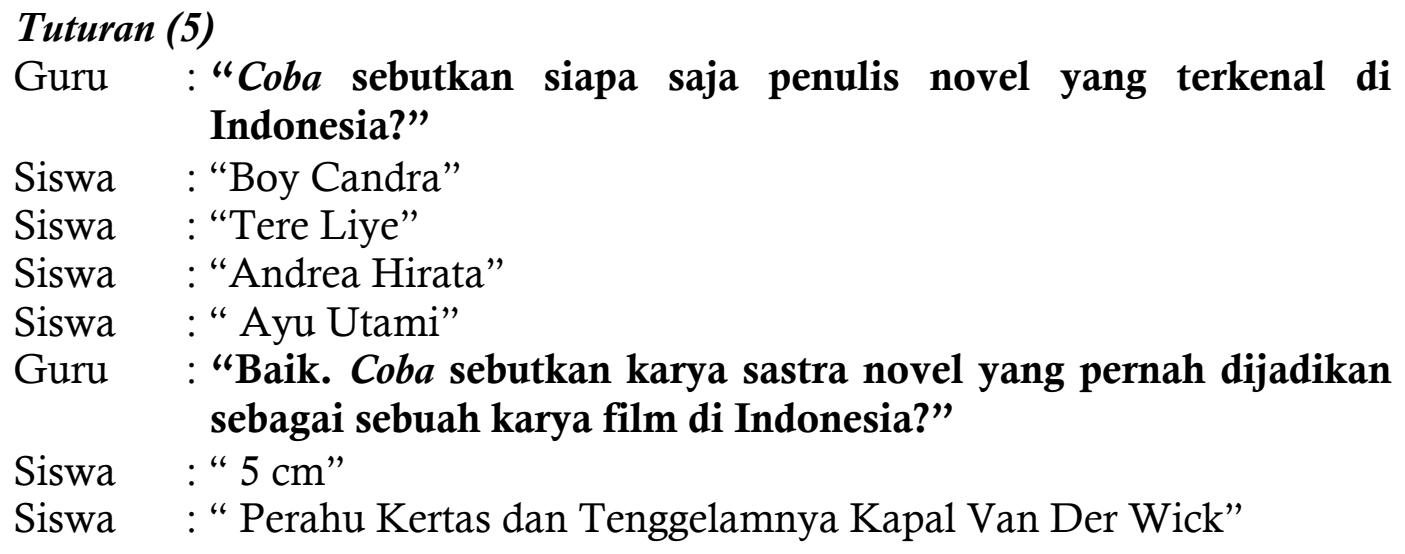

\section{Tuturan (6)}

Guru : "Apakah tugas minggu lalu sangat sulit?"

Siswa : "Tidak, Bu."

Guru : "Cepat kumpulkan ke depan tugas rumah minggu lalu!"

Siswa : "Iya, Bu."

Guru : "Mari kita bahas satu per satu tugas minggu lalu."

Siswa : Baik, Bu."

Tuturan guru dari tuturan (5) dan (6) merupakan tuturan perintah dengan menggunakan penanda kata "coba" dan "cepat" supaya perintah tersebut tidak terkesan basa-basi terhadap siswa agar dianggap sebagai tuturan yang tegas dan jelas. Konteks yang terjadi adalah guru sebagai orang yang menyampaikan informasi dan siswa sebagai orang yang menerima informasi. Topik tuturan (5), guru memerintahkan siswa untuk menyebutkan karya sastra novel dan penulis novel Indonesia yang ditandai dengan kata "coba" sehingga menghasilkan tuturan yang sopan dengan bertutur secara langsung. Kemudian, topik tuturan (6) guru memerintahkan siswa untuk mengumpulkan tugas ke depan kelas yang ditandai dengan kata "cepat" yang dianggap sedikit sopan dalam bertutur langsung.

\section{Bentuk Tuturan Persilakan}

Tindak tutur direktif berupa tuturan persilakan berasumsi ketika penutur mempersilakan lawan tutur untuk melakukan suatu hal mengenai kegiatan mempersilakan mitra tutur atau siswa. Misalnya, bentuk persilakan dengan menggunakan kata "silakan" dapat dilihat sebagai berikut. 


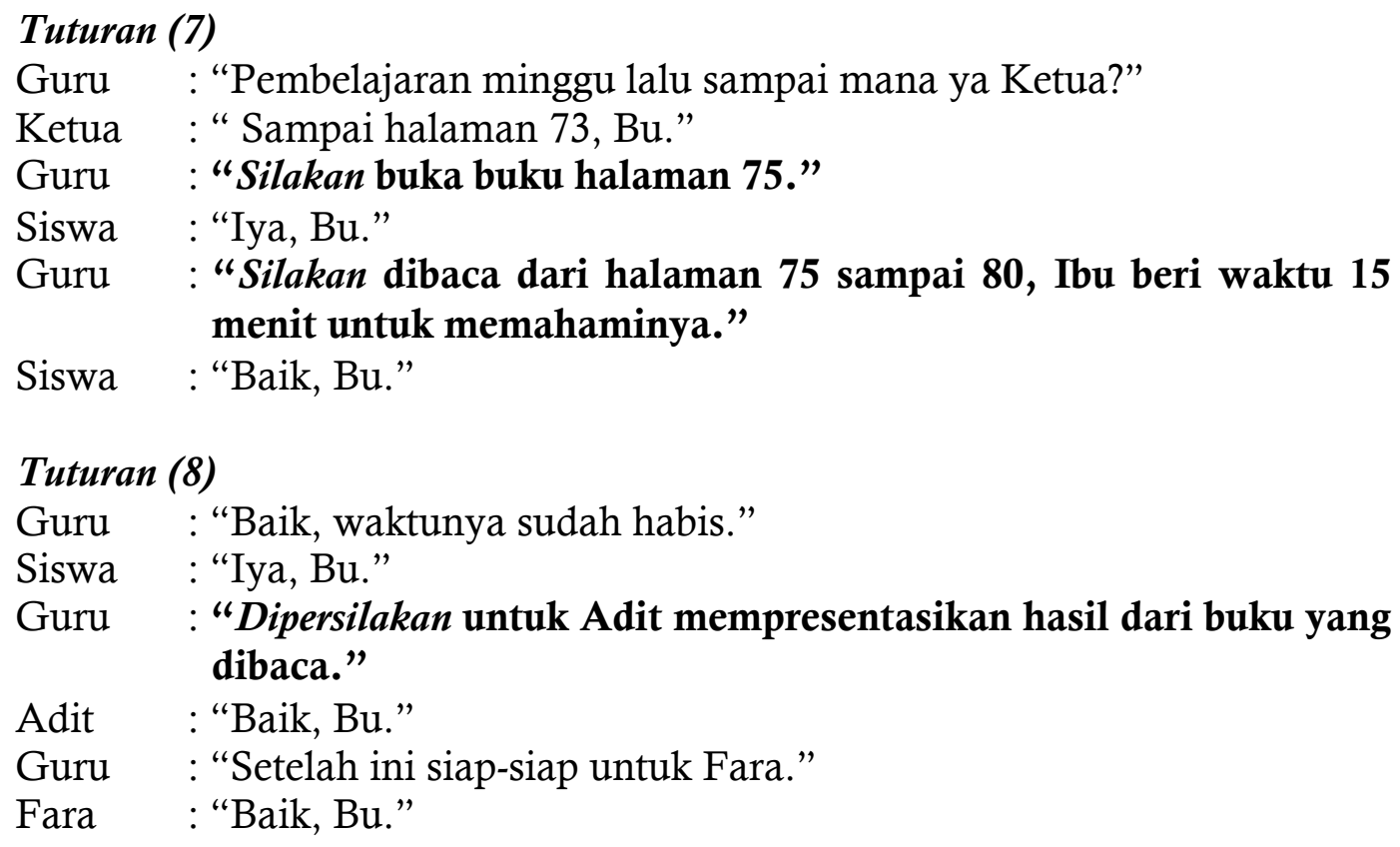

Tuturan guru dari tuturan (7) dan (8) merupakan tuturan perintah yang menggunakan kata silakan dan persilakan untuk mengungkapkan sebuah perintah agar terkesan baik dan santun. Konteks yang terjadi adalah guru sebagai orang yang menyampaikan informasi dan siswa sebagai orang yang menerima informasi. Topik tuturan (7) guru mempersilakan siswa untuk membuka buku pelajaran yang ditandai dengan kata "silakan" sehingga tercipta tuturan yang sopan ketika diucapkan secara langsung. Kemudian, topik tuturan (8) guru juga mempersilakan seorang siswa untuk presentasi di depan kelas, yang ditandai dengan kata "dipersilakan" sehingga terucap tuturan yang sopan secara langsung.

\section{Bentuk Tuturan Bertanya}

Dalam proses pembelajaran guru juga menggunakan tuturan bertanya. Dalam hal ini, jika guru ingin mengetahui hasil yang dipelajari siswa maka guru dapat bertanya mengenai proses pembelajaran pada saat itu. Oleh karena itu, guru akan lebih cenderung menggunakan pertanyaan langsung dalam pembelajaran di kelas, seperti bentuk tuturan bertanya dengan menggunakan kata $5 \mathrm{~W}+1 \mathrm{H}$.

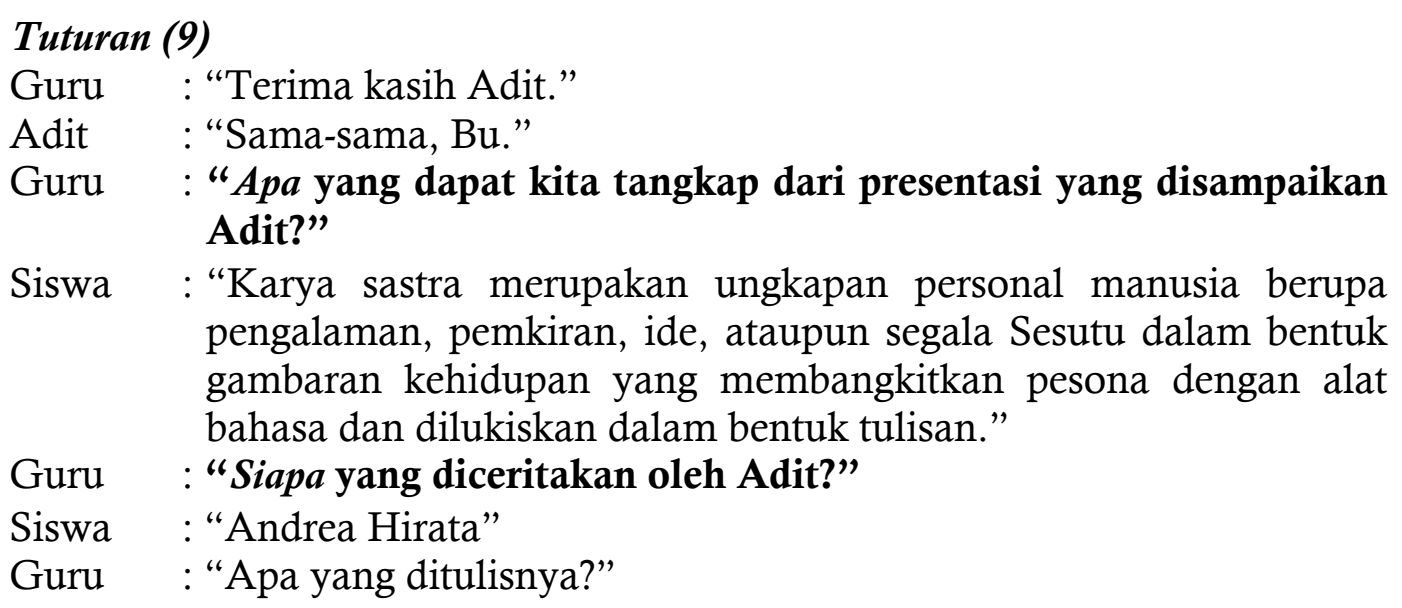




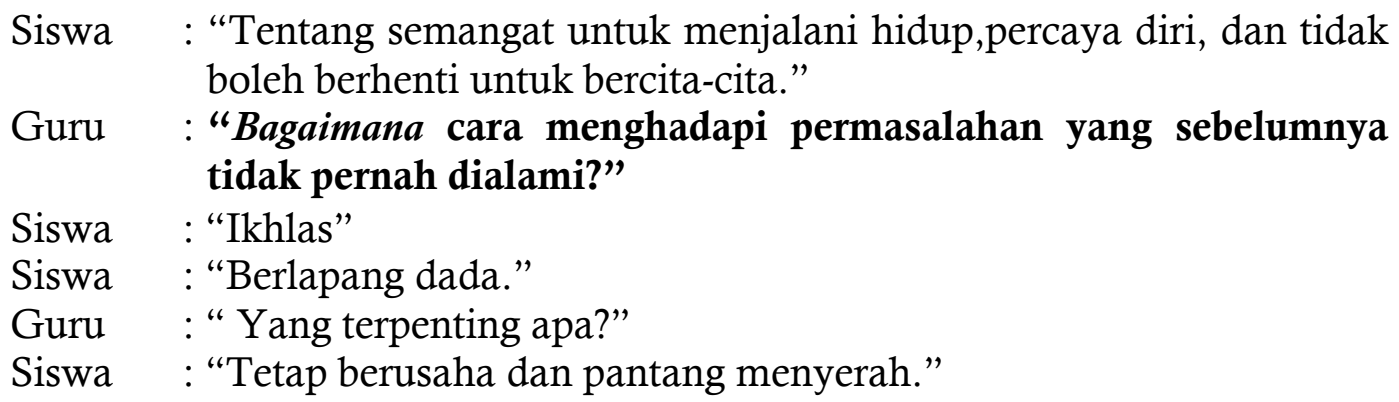

Tuturan guru dari tuturan (9) merupakan tuturan bertanya dengan menggunakan penanda kata apa, siapa, dan bagaimana agar apa yang dipertanyan sesuai dengan situasi dan bertanya secara langsung. Konteks yang terjadi adalah guru sebagai orang yang menyampaikan informasi dan siswa sebagai orang yang menerima informasi dan juga membagi informasi. Pada tuturan (9) guru memberikan pertanyaan kepada siswa yang ditandai dengan kata tanya "apa, siapa, dan bagaimana" sehingga dalam bertutur guru mengucapkannya secara langsung dan sopan.

\section{PENUTUP}

Dari hasil penelitian, pada saat proses pembelajaran Bahasa Indonesia berlangsung, ditemukan data bahwa guru memakai lima tindak tutur direktif, yaitu bentuk tuturan meminta, tuturan harapan, tuturan perintah, tuturan persilakan, dan tuturan bertanya. Konteks yang terjadi dalam bertutur di kelas, guru sebagai orang yang menyampaikan informasi dan siswa sebagai orang yang menerima informasi sekaligus memberikan informasi. Bentuk tuturan meminta dilihat dari kata tolong dan ayo, bentuk tuturan harapan dilihat dari kata harap atau harapan, bentuk tuturan perintah dilihat dari kata coba dan cepat, bentuk tuturan persilakan dilihat dari kata silakan, dan bentuk tuturan bertanya dilihat dari kata apa, siapa, dan bagaimana. Dalam mengungkapkan sebuah tindak tutur direktif harus dilakukan secara langsung. Hal ini disebabkan karena adanya keterkaitan antara hubungan dengan status sosial yang terjadi di antara guru dan siswa. Tak hanya itu, guru dan siswa dalam berinteraksi juga memperhatikan kesopanan ketika bertutur secara langsung.

\section{DAFTAR PUSTAKA}

Ardianto. (2013). Tindak Tutur Direktif Guru dalam Wacana Interaksi Kelas Anak Tunarungu. Litera, 12(1), 1-12. https://doi.org/10.21831/ltr.v12i01.1318

Darwis, A., \& Ketut, I. (2018). Tindak Tutur Direktif Guru di Lingkungan SMP Negeri 19 Palu: Kajian Pragmatik. Bahasa dan Sastra, 4(2), 21-30. http://jurnal.untad.ac.id/jurnal/index.php/BDS/article/view/10060

Elmita, W., Ermanto, E., \& Ratna, E. (2013). Tindak Tutur Direktif Guru dalam Proses Belajar Mengajar di TK Nusa Indah Banuaran Padang. Jurnal Pendidikan Bahasa dan Sastra Indonesia, 1(2), 139-147. https://doi.org/10.24036/1301019883

Falia, K. Y. R., Thahar, H. E., \& Tressyalina, T. (2018). Kesantunan Tindak Tutur Najwa Shihab dalam Gelar Wicara Mata Najwa di Episode 100 Hari AniesSandi. Jurnal Pendidikan Bahasa dan Sastra Indonesia, 7(3), 114-120. https://doi.org/10.24036/100720-019883

Hermita, L., Agustina, A., \& Nasution, M. I. (2014). Tindak Tutur Direktif 
Pedagang Pakaian dalam Bahasa Mandailing di Pasar Ujung Gading Kabupaten Pasaman Barat. Jurnal Bahasa dan Sastra, 2(2), 62-73. https://doi.org/10.24036/833550

Hudiyono, Y., Rokhmansyah, A., \& Elyana, K. (2021). Class conversation strategies in junior high schools: Study of conversation analysis. Cypriot Journal of Educational Sciences, $16(2), \quad 725-738$. https://doi.org/10.18844/CJES.V16I2.5649

Imaniar, I. (2013). Penggunaan tindak tutur ekspresif kalangan remaja Di Kota Palu. Bahasa dan Sastra, 2(1), 1-10. http://jurnal.untad.ac.id/jurnal/index.php/BDS/article/view/2155

Kaka, P. W. (2017). Analisis terhadap Kesantunan Tindak Tutur Direktif Guru dalam Pembelajaran di SD Inpres Bajawa VI Kecamatan Bajawa Kabupaten Ngada. Jurnal Ilmiah Pendidikan Citra Bakti, 4(1), 114-127. http://www.ejournal.citrabakti.ac.id/index.php/jipcb/article/view/87

Larassaty, S., Syahrul, R., \& Gani, E. (2016). Representasi Tindak Tutur Direktif Bahasa Indonesia Siswa Kelas XI SMA Negeri 15 Padang. Jurnal Pendidikan Bahasa dan Sastra Indonesia, 5(2), 431-437. https://doi.org/10.24036/10015019883

Maryunis, M., Amir, A., \& Tressyalina, T. (2012). Tindak Tutur Direktif Pedagang Sayur-mayur di Pasar Alahan Panjang Kabupaten Solok. Jurnal Bahasa Dan Sastra, 1(1), 73-83. https://doi.org/10.24036/82260

Nurhamida, N., \& Tressyalina, T. (2019). Strategi Bertutur dalam Tindak Tutur Ekspresif Bahasa Indonesia pada Kegiatan Diskusi. Jurnal Pendidikan Bahasa dan Sastra Indonesia, 8(4), 21-29. https://doi.org/10.24036/106907-019883

Prasetyo, R. I. (2018). Tindak Tutur Direktif Pendidik dalam Mengelola Interaksi Belajar Mengajar di SMA Negeri 1 Wirosari Grobogan: Kajian Analisis Wacana Kelas. Universitas Negeri Semarang. http://lib.unnes.ac.id/40546/1/tesis\%20full.pdf

Putra, H. N. P. (2020). Tindak Tutur Ilokusi Direktif dalam Anime D-frag Episode 1-12 Karya Tomoya Haruno. HIKARI, 4(1), 30-39. https://jurnalmahasiswa.unesa.ac.id/index.php/hikari/article/view/32354

Rahmawati. (2020). Tindak Tutur Direktif dalam Percakapan Nonformal Mahasiswa Prodi Pendidikan Bahasa dan Sastra Indonesia FKIP Universitas Tadulako. Jurnal Bahasa Dan Sastra, 5(3), 1-15. http://jurnal.untad.ac.id/jurnal/index.php/BDS/article/view/12723

Sumarti, S. (2015). Strategi Kesantunan dan Ketidaksantunan dalam Tindak Tutur Direktif Guru. AKSARA: Jurnal Bahasa dan Sastra, 16(1), 63-73. http://jurnal.fkip.unila.ac.id/index.php/aksara/article/view/12167

Sunarwan, E., Rohmadi, M., \& Anindyarini, A. (2014). Analisis deiksis dalam cerpen siswa kelas X SMA Negeri 1 Karanganyar. Jurnal Basastra, 2(3), 1-11. https://jurnal.fkip.uns.ac.id/index.php/bhs_indonesia/article/view/7788

Syukur, S. E. H., Soe'oed, R., \& Mulawarman, W. G. (2020). Tindak Tutur Remaja sebagai Anak Tunggal dalam Interaksi Sehari-Hari di Kelas: Kajian Sosiopragmatik. Diglosia: Jurnal Kajian Bahasa, Sastra, dan Pengajarannya, 3(4), 445-454. https://doi.org/10.30872/diglosia.v3i4.128

Tressyalina, T. \& Anisa, H. (2020). Strategi Tindak Tutur Langsung dan Tidak Langsung Pedagang dalam Menerima dan Menolak Pembeli di Pasar Aur Kuning Bukittinggi. Nusa: Jurnal Ilmu Bahasa dan Sastra, 15(2), 253-262. https://doi.org/10.14710/nusa.15.2.253-262 
Vilayati, I. A., Agustina, A., \& Tressyalina, T. (2012). Kesantunan berbahasa Minangkabau dalam tindak tutur direktif antara anak dan orang tua di Ikur Koto Kecamatan Koto Tangah Padang. Pendidikan Bahasa Indonesia, 1(1), 546-556.

Wati, I. N., Rusminto, N. E., \& Riadi, B. (2017). Tindak Tutur Direktif Guru Perempuan dalam Pembelajaran Bahasa Indonesia Kelas XI SMA. AKSARA: Jurnal Bahasa dan Sastra, 18(2), 100-111. http://jurnal.fkip.unila.ac.id/index.php/aksara/article/view/14346

Yuliana, R., Rohmadi, M., \& Suhita, R. (2013). Daya Pragmatik Tindak Tutur Guru dalam Pembelajaran Bahasa Indonesia pada Siswa Sekolah Menengah Pertama. Jurnal Basastra, 1(2), 280-293. https://jurnal.fkip.uns.ac.id/index.php/bhs_indonesia/article/view/2146 